\title{
Additional TAXonomic Features of PINGUiCUla CHILENSIS
}

AYMERIC ROCCIA • Chambéry•France • aymeric.roccia@live.fr

Keywords: Pinguicula chilensis, Pinguicula antarctica, Pinguicula australandina.

Recently, Gluch (2017) synonymized the name Pinguicula chilensis Clos with P. antarctica Vahl and described two new species $P$. australandina Gluch and $P$. nahuelbutensis Gluch, referring to the plants previously known as "P. chilensis".

The main reason for which Gluch (2017) considered that the isotype of Pinguicula chilensis (specimen Gay 169 (P photo!), designated as the lectotype by Dominguez et al. (2017) and held at the Muséum national d'Histoire naturelle (P), in Paris) is in fact $P$. antarctica, is the length of the fruiting scapes. On that specimen, Gluch (2017) measured $9.5 \mathrm{~cm}$ for the longest scape, but considered that scapes of $P$. chilensis (referred to as $P$. australandina) can only reach $2-5 \mathrm{~cm}$ long. This range is based on Ernst (1961), and was adopted literally by Casper (1966), and later by Lampard et al. (2016). However, the variability of $P$. chilensis has been further investigated since Casper's monograph of the genus Pinguicula (Casper 1966). For example, Rodríguez et al. (2000) extended the range of the flowering scape length to $2-8 \mathrm{~cm}$. Recently, Michail Belov published pictures from the Laguna del Maule, in Talca province in Chile (Figs. 1 \& 2). Those individuals display the typical lilac flowers with long conical spur of $P$. chilensis, as described by Clos (1849), Ernst (1961), and Casper (1966). Moreover, the Laguna del Maule represents one of the northernmost location of this species, very far from any populations of the $P$. antarctica distribution range known to date. No doubt that those specimens clearly belong to $P$. chilensis sensu Ernst (1961) and Casper (1966). Fortunately,

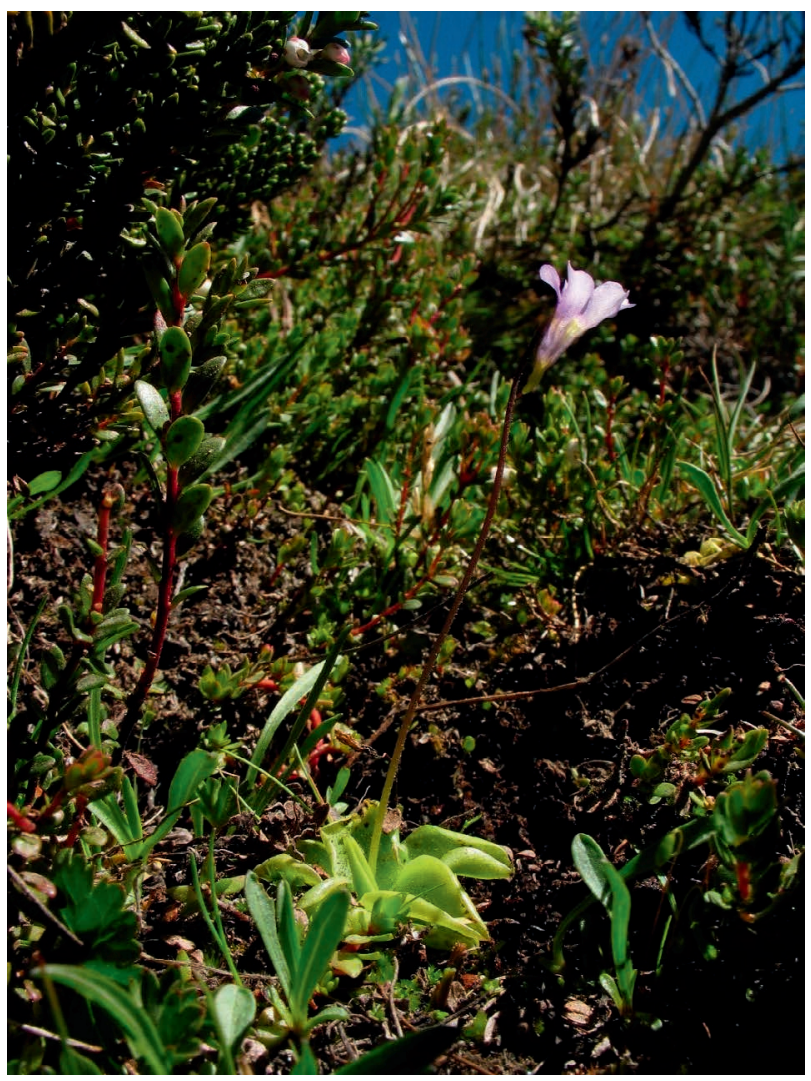

Figure 1: A flowering Pinguicula chilensis in its habitat at the Laguna del Maule, Provincia de Talca, Chile. Photograph by Michail Belov. 


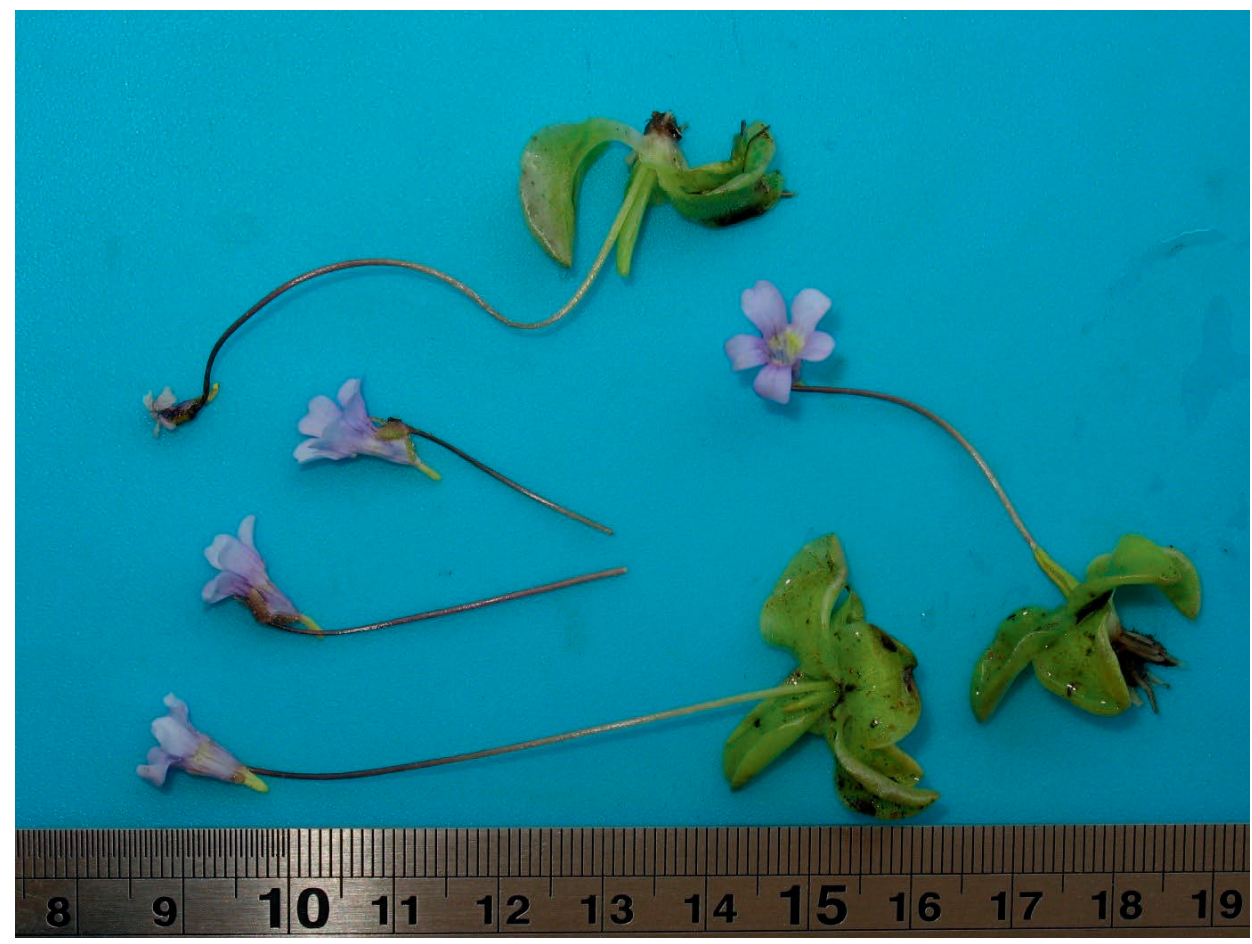

Figure 2: Pinguicula chilensis flowers and entire flowering plants collected at the Laguna del Maule, Provincia de Talca, Chile. Photograph by Michail Belov.

Michail Belov also took pictures of the flowering scapes against a ruler (Fig. 2). Most scapes are not removed entirely, as the scape bases are mostly violet whereas they are supposed to be green when fully pulled out. However, the longest entire scape is $7 \mathrm{~cm}$ long. In addition, although unmeasured, the scape shown on Figure 1 looks even longer. In this respect, the measure of $9.5 \mathrm{~cm}$ on the lectotype should not be regarded as inconsistent with $P$. chilensis characteristics.

Nonetheless, a matter of doubt could remain because of the location of Gay's collection which is used as lectotype (Gay 169 (P)). This plant originates from "el Corral, cerca de Daglipulli" (Valdivia province). Corral is a coastal city, near Valdivia, and Daglipulli is a small village close to La Unión (Ranco province), situated at an elevation of $c a .80 \mathrm{~m}$ a.s.1. Such environmental conditions are not the expected ones for Pinguicula chilensis (Casper 1966; Rodriguez et al. 2000; Lampard et al. 2016). However, a small mountain range called Cordillera Pelada occurs between both localities, peaking at $1042 \mathrm{~m}$ a.s.1. Rodriguez et al. (2000) mentioned that $P$. chilensis can be found at elevations as low as $1000 \mathrm{~m}$ a.s.1. and Pinguicula chilensis is considered to occur at lower elevations to the south, as climate becomes colder (Lampard et al. 2016). It would then not be inconceivable to find a location at such low elevation at the latitude of Corral.

In addition, Gluch (2017) discarded the possibility that this species could occur on the Cordillera Pelada based on the fact the peat-bogs occurring on this mountain range are made of "typical Antarctic vegetation consisting of the dominating species Donatia fascicularis [Stylidiaceae], Astelia pumila [Asteliaceae], Sphagnum acutifolium [Sphagnaceae], and Tribeles australis [Escalloniaceae]. In between this vegetation, Reiche stated that Carpha viridis [Cyperaceae], Pinguicula chilensis 
[Lentibulariaceae], Acaena pumila [Rosaceae], Drosera uniflora [Droserceae], and Schizaea fistulosa [Schizaeaceae] can be found". However, Rodriguez et al. (2000) stated that P. chilensis does occur among Donatia fascicularis, Astelia pumila, Sphagnum magellanicum, and Tribeles australis.

Finally, a body of noteworthy elements can be noticed when reviewing the original description of Pinguicula chilensis (Clos 1849). Firstly, both P. chilensis and P. antarctica are described in this work, thus the author knew both species at that time. Secondly, Clos (1849) mentioned about Pinguicula chilensis: "bohordos [...] terminados por una sola flor poco colgante" (scapes are terminated by a single flower only shallowly inclined), although he added that "se habian ya concluidas las flores" (flowers were already faded). With little doubt, Clos seems to have described the skyward-facing flower of $P$. chilensis, as opposed to $P$. antarctica which produces flowers held horizontally. This description also suggests that Clos has observed $P$. chilensis flowers and its diagnostic characters such as the spur shape, but for an unknown reason, he did not describe it. One can only imagine that Clos really knew what he was doing when describing P. chilensis.

All-in-all, those reasons support the fact that Clos' Pinguicula chilensis is a distinct species from Vahl's $P$. antarctica and that Gluch's $P$. australandina is a later synonym of $P$. chilensis Clos based on a different interpretation of the morphological and ecological variations of that species:

Pinguicula chilensis $\mathrm{Clos}=$ P. australandina Gluch, syn. nov.

Acknowledgements: The author would like to thank Michail Belov for kindly providing his pictures and giving the authorization to publish them in this article.

\section{References}

Casper, S.J. 1966. Monographie der Gattung Pinguicula L. Bibliotheca Botanica 127/128. 209 p.

Clos, D. 1849. In: Gay, C. Historia fisica y politica de Chile. Botanica, tomo cuarto. E. Trunot \& c. Paris, France. 516 p.

Dominguez, Y., Panfet Valdés, C.M., and Miranda, V.F.O. 2017. Typification of names in the genus Pinguicula L. (Lentibulariaceae). Phytotaxa 312(2): 179-198.

Ernst, A. 1961. Revision der Gattung Pinguicula. Botanische Jahrbücher für Systematik, Pflanzengeschichte und Pflanzengeographie 80: 145-194.

Gluch, O. 2017. Revision of Pinguicula (Lentibulariaceae) in Chile and Argentina. Carnivorous Plant Newsletter 46(4): 121-131.

Lampard, S., Gluch, O., Robinson, A., Fleischmann, A., Temple, P., McPherson, S., Roccia, A., Partrat, E., and Legendre, L. 2016. Pinguicula of Latin America. Redfern Natural History Productions. Poole, Dorset, England. 361 p.

Rodríguez, R., Urbina, A., and Valenzuela, S. 2000. Estudios anatomicos en Pinguicula chilensis Clos (Lentibulariaceae). Gayana Botánica 57(1): 101-103. 